\title{
Knowledge, Skills and Competencies of Hospitality Companies in the South Moravian Region
}

\author{
Klapalová Alena
}

\begin{abstract}
In 2009, a survey focused on barriers to entrepreneurship among managers and/or owners of companies in the hospitality industry in the South Moravian Region was carried out (Klapalová, 2011) at the College of Business and Hotel Management in Brno. Results of this survey revealed that knowledge together with skills and competencies was considered to be the biggest barrier to sustainable successful entrepreneurship of these companies and this perception was also confirmed by Spearman's correlations analysis with statistically significant coefficient at the 0.05 level (Spearman's rho $=0.214, \mathrm{p}=0.18$ ), when analyzing the relation to financial performance of companies. The issue of knowledge was not investigated deeper in the survey but it raised several questions for further research. This paper offers preliminary and partial results of an inquiry done during the autumn and winter 2011 and spring and summer 2012 which takes up the previous survey from 2009 with the aim to explore the types of knowledge, skills and competencies perceived as the most important for company success and as the most missing in nowadays entrepreneurship of inquired companies. Three relationships of knowledge categories were analysed: relation to the age and size of companies and relation to the indicators of financial performance. The findings have several managerial implications, both for business practice and educational organisations.
\end{abstract}

Key words: knowledge, skills, competencies, age of companies, size of companies, profitability

\section{INTRODUCTION}

The current marketplace is undoubtedly extremely knowledge-based. Knowledge is one of the most - if not the most important both building stones and mortar for the existence of organizations. Knowledge and knowledge integration throughout the organizations is leading critical source of success (Kiessling et al., 2009) and basic source of competitive advantage and competitiveness (Jaworski and Kohli, 1993; Grant, 1996; Conner and Prahalad, 1996). Knowledge is a vague concept and due to the nearly absolutely connection to human beings, content of knowledge depends on individual person and their processing of the perceived information and contextualization based on individual experiences (Greiner et al., 2007) and individual capabilities, skills and competences, that in organisational life should lead to the planned and desired actions and/or reactions. This is co called tacit knowledge that is difficult to catch, formalize, codified, store and communicate and disseminate (Nonaka and Takeuchi, 1995). But companies as well as all other organisations must be a bundle of special knowledge that helps to achieve stated goals and given purpose. For business knowledge referring to marketplace and performance of companies belongs to the mostly essential one. Such types of knowledge are more or less categorized, the content is more or less standardised and the expectation of the results of such 
knowledge "working" is more or less clear. It is the case of a combination of tacit and so called explicit knowledge, that can be expressed verbally (Nonaka and Takeuchi, 1995).

The paper is aimed at the investigation of potential differences among several hospitality business companies characteristics (size, age and financial performance) related to several types of knowledge, skills and competencies that are considered by managers of companies as: a) the most important for the sustainable success and competitiveness and b) the most missing in their business. Seven types of knowledge, skills and competences were evaluated by the respondents in the questionnaire survey.

\section{THEORETICAL BACKGROUND}

Region of South Moravia occupies relative stabile position of the second and third most attractive tourism destination of the Czech Republic for both domestic and foreign tourists according the number of tourists (after Prague and Karlsbad Region) in 2010 (Czech statistical office: Statistical Yearbook of the Jihomoravský Region, Tourism, 2010). The business in the hospitality sector is extremely dependent on very high heterogeneity of customer demand and offer must be quite flexible to react to changing needs and wants. Relative lower capital intensity and requirements of entry capital together with other relatively very small entry barriers covering manpower number or special education and knowledge offer many opportunities to start and continue business (Jaafar et al., 2010).

Although not every entrepreneur wants to do business in large scale (and some even not in middle scale) (Bartlett and Bukvič, 2001), there probably would not be many owners who prefer to have their business be unsuccessful. Pasanen citing Simon (1996) stresses that "the most important and the most challenging business goal is long-term survival (Pasanen, 2005). Success in entrepreneurship can mean stability (after reaching some level of development) or growth, both usually measured with financial measures of performance, e.g. profit maximization, profit growth, turnover growth etc. Success can be seen also in such measures like customer satisfaction and loyalty or growth of customers' number (not necessarily connected to financial performance).

Hospitality is highly human-resource-dependent industry and its success and competitiveness depends on quality of people - not only managers but staff as well (Jones, 2005). Lower level of professionalism and problems with qualified personnel recruitment represent the most often cited barriers for competitiveness, growth and sustainability of entrepreneurship in this industry (Pasanen, 2005; Yilmaz, 2009). Aidis and Sauka's (2005) survey results of small enterprises in 23 transition countries show that human resources and skills are typical constraints for development during the later transition stages of economy. Lack of qualified employees and expertise, financial problems, and lack of innovation or innovativeness are the most intensive perceived internal barriers of Turkish managers of small and middle tourism companies. In the survey also marketing problems and difficulties of preparing a strategic plan - internal barrier - and quality deficiencies, high costs and uncertainty in business environment that can be taken as barriers coming both from the internal as well as from external environment were also introduced (Yilmaz, 2009). Both factors can be viewed from two perspective - external - lack of skilled and quality work force on market and internal - inability(or low competence) to get and retain good staff. 
Concerning the point of qualified human resources we can also mention the results of the UK Federation of Small Business survey in 2004 when one of the biggest barriers to training is cost (Carter et al, 2004). If we add also the factor of time (in the sense of effort to employ less than more employees that is typical feature of many enterprises in hospitality), many small enterprises do not spend much on training, if anything at all. Entrepreneur's personality (education, managerial experience, lack of motivation and commitment and skills), bad staff with wrong attitudes, age and size of company (the younger and smaller are more vulnerable, weak business concept, lack of strategy and vision belong to those list of issues are most often reasons of SMEs failures in general (Pasanen, 2005). Owner motivation (in case of many small and most of middle enterprises in hospitality owners usually manage these companies) and lack of strategic planning because of lack of time, lack of expertise, inadequate knowledge of planning processes, reluctance to share strategic ideas with employees and others, size of business, business life cycle stage and other internal implementation barriers were assigned as the strategic planning barriers of SMEs also by Wang, Walker and Redmond according their research (2007).

Knowledge are one of the strategically important resources of organisations (and companies) (Zack, 1999), creating base for innovation activities and flexible adaptation to the environmental changes and so stand for the primary driver of development and ability to compete successfully (Gupta et Govindarajan, 2000; Jiménez-Jimenez et al, 2008). There is no solely existing definition of knowledge. According Davenport and Prusak (1998) "Knowledge is a fluid mix of framed experience, values, contextual information, and expert insight that provides a framework for evaluating and incorporating new experiences and information" (Davenport et Prusak, 1998, s. 5).

Knowledge contains know-how, information, practices, skills, competencies (Keupp et al, 2011) and they can be divided into several categories or types, e.g. technical, entrepreneurial, organisational (Adenfelt and Lagerström, 2008) or production - functional (marketing, distribution, product and process design, purchasing and knowledge concerning managerial system and management practices (Gupta and Govindarajan, 2000). If we stay with competencies, several types can be recognized, among all two are fundamental for company survival, concretely work management competency and interpersonal management competency. Management competencies are connected to the special skills of managers to provide specific task in the frame of management (Sudsakorn and Swierczek, 2009).

Every organisation or company has its own individual mix or bundle of knowledge, skills and practices. Unfortunately not always this existing mix corresponds with the need of practice and everyday business due to various circumstances and reasons. But managers should be at least conscious which knowledge is fundamental for their business, which are important but not indispensable at the moment and which knowledge can be even excessive or useless. Only consciousness or knowledge of this kind of resources enables managers to manage knowledge properly and effectively. For the question of knowledge management see for instance Quintas et al (1997).

\section{SURVEY METHODOLOGY}

The survey presented in this paper follow up the survey realized in the year 2009 focused at barriers of entrepreneurship of companies in hospitality (accommodation services) localized 
in the Region of South Moravia. From 13 barriers (from the internal as well as from external environment) lack of needed and desired knowledge, skills and competencies of employees and managers was ascertained as the most problematic barrier for surveyed companies. This finding spurred the formulation of new questions proper for to continue in the research. Among all those questions also the type of knowledge, skills and competencies has been considered worth of investigation.

All companies from the survey in 2009 were contacted with the request for being again the respondents in the survey which took place during the autumn and winter 2011 and spring and beginning of summer 2012 and the new questionnaire was accompanying the request. From 123 in the year 2009109 responses were acquired. 37 new respondents through random sampling were after gained to have bigger sample, so finally the answers from 134 companies were analyzed. This number does not enable to generalize the results but offers the ability to formulate some tendencies at least.

From the "old questionnaire" seven questions were used repeatedly, concretely:

a) age of the companies, where three categories of the length of existence were involved companies established before the year 1990, between the year 1990 and 2000 and after the year 2000;

b) size of companies measured in this case by number of beds for guests in companies and again divided into three groups - small - up to 10 beds, middle - 10 to 50 beds and big - more than fifty beds;

c) measure of financial performance - three measure were used after the analysis to the opened question - respondents were asked to state if their company was profitable or in loss in the last three years. These three categories of responses are: profit, no profit/no loss and in loss;

d) share of foreign clients - in this case respondents should choose from two possibilities - up to $50 \%$ more than $50 \%$ foreign clients in average;

e) degree of customer impact on success and competitiveness (5-point scale)

f) degree of impact of financial resources on success and competitiveness (5-point scale)

g) degree of impact of knowledge, skills and competencies on success and competitiveness (5-point scale).

The last three questions originate from the 13 barriers and for the first two question the reason to use them again was the economic situation in tourism and hospitality in the country and globally. These criteria can be critical for survival and they are closely connected to the types of knowledge surveyed. In this paper results for the points d), e) and f) are not presented.

Six new questions were created to find out the types of knowledge, skills and competencies which managers are interested in and worried with in their everyday practice. The types of knowledge, skills and competencies were formulated during the personal interviews with 5 managers from this field of entrepreneurship prior to survey. Two questions were open - respondents were asked to introduce types of knowledge, skills and competencies that: 1. are the most important for the success and competitiveness and 2. are the most missing in their contemporary business. Two questions have character of scale and are multi-items - seven types of knowledge, skills and competences were introduced and respondents ticked the proper point on the 5-points scale for: 
1. impact evaluation of each type from "pivotal impact" to "absolutely no impact" and 2. lack of type of knowledge from "not missing at all" to "absolutely missing". Results of these four questions are not introduced in this paper except some references. The last two questions were very simple - respondents should choose from the list of seven types of knowledge which one (the only one) is: 1. the most important for the success and 2. the most missing one as resource.

For this paper only very simple statistics was employed - frequencies, relative frequencies and crosstabulation. The primary goal was to get the answer to the research question if there are any differences in frequencies of types of knowledge, skills and competencies and if yes, if and how these frequencies are related to the size, age and financial performance of companies.

\section{RESULTS}

Tab.1 presents summary results of descriptive statistics.

Tab. 1 - Descriptive statistics results for 134 companies in sample. Source: authors 'analysis

\begin{tabular}{|c|c|c|c|c|c|c|c|c|}
\hline \multicolumn{4}{|c|}{ Age of companies } & \multicolumn{3}{c|}{ Size of companies } & \multicolumn{3}{c|}{ Financial performance } \\
\hline $\begin{array}{c}\text { before } \\
1990\end{array}$ & $\begin{array}{c}9000 \\
-2000\end{array}$ & $\begin{array}{c}\text { after } \\
2000\end{array}$ & $\begin{array}{c}\text { up to } 10 \\
\text { beds }\end{array}$ & $\begin{array}{c}10-50 \\
\text { beds }\end{array}$ & $\begin{array}{c}\text { more } \\
\text { than } 50 \\
\text { beds }\end{array}$ & profit & $\begin{array}{c}\text { no } \\
\text { profit/ } \\
\text { no loss }\end{array}$ & loss \\
\hline 11 & 47 & 76 & 44 & 62 & 28 & 50 & 65 & 19 \\
\hline
\end{tabular}

As can be seen be seen from the table, the smallest number of companies concerns those that were established before the year 1990, the highest those established in the last 11 years. Majority of companies belong to smaller and middle-sized companies and more than one third is profitable as well as nearly half of companies is not in loss but their financial performance can be assigned as relatively not bad.

In the following text individual types of knowledge, skills and competencies that were introduced as the most missing and considered as the most important are analysed. In Tables and Graphs abbreviations are used. Legend for them is in the next paragraph:

CRM - customer relationship management- knowledge, skills - if possible and competencies to handle with customers and/or to create and promote relations with them;

MKT - marketing knowledge, skills and competencies of methods, techniques especially for the marketing mix practice;

FIN - knowledge, skills and competencies of financial management and of methods and techniques applied for financial performance;

MNG-in - knowledge, skills and competencies to manage internal issues of companies, e.g. organising, leadership, control etc.;

MNG-ex - knowledge, skills and competencies to manage external issues of companies, e.g. suppliers relations, destination relations, legislation etc.;

Lang - knowledge of foreign languages and skills and competence for the use of languages;

ICT - knowledge, skills and competencies to use information and communication (ICT) facilities.

Summarizing the results for the types of knowledge for all respondents, marketing and external managerial knowledge, skills and competencies are two the most frequently mentioned missing with the share of $25,4 \%$ from all types of knowledge and financial knowledge as the third most often mentioned missing type. This type is recognized as the most often introduced from the 
most important ones for success and competitiveness (29,1\%) followed by marketing and customer relations (both 24,6\%). Languages and ICT knowledge were not perceived so important at all.

\subsection{Age of companies}

Results of crosstabulation of companies' age and the most missing knowledge types show that the biggest difference can be found between oldest and youngest companies with customer relations and financial followed by marketing while nearly no or no differences among all three age groups are revealed with internal managerial knowledge. This can be probably explained by the fact that long practice can be very helpful for learning and understanding various circumstances and situations that can be connected with the customers, market and finance. These three types together with external managerial knowledge and languages that have common results also show time tendency that is in favour for older companies. No tendency is clear with internal managerial knowledge. This is maybe for the fact of human resource management that is very sensitive and individual, even much more than customer relationships.

Tab. 2 - Age and type of the most missing knowledge, skills and competences within the types. Source: authors 'analysis

\begin{tabular}{|l|l|l|l|}
\hline & before 1990 & $1990-2000$ & after 2000 \\
\hline CRM (N=9) & $0,0 \%$ & $11,1 \%$ & $88,9 \%$ \\
\hline MKT (N=34) & $5,9 \%$ & $29,4 \%$ & $64,7 \%$ \\
\hline FIN (N=25) & $4,0 \%$ & $32,0 \%$ & $64,0 \%$ \\
\hline MNG-in (N=18) & $27,8 \%$ & $44,4 \%$ & $27,8 \%$ \\
\hline MNG-ex (N=34) & $5,9 \%$ & $41,2 \%$ & $52,9 \%$ \\
\hline Lang (N=7) & $0,0 \%$ & $42,9 \%$ & $57,1 \%$ \\
\hline ICT $(\mathrm{N}=7)$ & $14,3 \%$ & $42,9 \%$ & $42,9 \%$ \\
\hline
\end{tabular}

Managers of companies that were established before the year 1990 feel that internal managerial knowledge, skills and competencies are those that miss the most $(45,5 \%$ from total number of companies in this age group). This is just on contrary to the youngest companies for which marketing knowledge $(28,9 \%)$ lacks the most often, followed by external managerial knowledge $(23,7 \%)$. External managerial knowledge is perceived with the highest share also by "middleaged" companies $(29,8 \%)$ as can be seen in Tab. 3 .

Tab. 3 - Age and type of the most missing knowledge, skills and competences within the age groups. Source: authors 'analysis

\begin{tabular}{|l|c|c|c|c|}
\hline & $\begin{array}{c}\text { bef. 1990 } \\
(\mathrm{N}=11)\end{array}$ & $\begin{array}{c}1990-2000 \\
(\mathrm{~N}=47)\end{array}$ & $\begin{array}{c}\text { after } 2000 \\
(\mathrm{~N}=76)\end{array}$ & $\begin{array}{c}\text { share in } \% \\
(\mathrm{~N}=134)\end{array}$ \\
\hline CRM & $0,0 \%$ & $2,1 \%$ & $10,5 \%$ & $6,7 \%$ \\
\hline MKT & $18,2 \%$ & $21,3 \%$ & $28,9 \%$ & $25,4 \%$ \\
\hline FIN & $9,1 \%$ & $17,0 \%$ & $21,1 \%$ & $18,7 \%$ \\
\hline
\end{tabular}




\begin{tabular}{|l|c|c|c|c|}
\hline MNG-in & $45,5 \%$ & $17,0 \%$ & $6,6 \%$ & $13,4 \%$ \\
\hline MNG-ex & $18,2 \%$ & $29,8 \%$ & $23,7 \%$ & $25,4 \%$ \\
\hline Lang & $0,0 \%$ & $6,4 \%$ & $5,3 \%$ & $5,2 \%$ \\
\hline ICT & $9,1 \%$ & $6,4 \%$ & $3,9 \%$ & $5,2 \%$ \\
\hline total & $100,0 \%$ & $100,0 \%$ & $100,0 \%$ & $100,0 \%$ \\
\hline
\end{tabular}

Financial knowledge, skills and competencies are those that are regarded as the most important for success and competitiveness by the youngest companies $(71,8 \%)$, while for nearly all of the oldest companies this type of knowledge is not on the top of the list. Similar situation is with internal managerial knowledge (youngest $-66,7 \%$ in comparison to the oldest $-0,0 \%$ ), as well as external managerial knowledge and customer relationship (see Tab. 4). On the contrary there are only small differences between frequencies in the case of marketing knowledge. Although the total number of responses is very small - only seven - with language knowledge, it is the middle-aged and oldest companies that rank this type for the most important one. Nevertheless, this fact can be just the random phenomenon of individual cases.

Tab. 4 - Age and type of the most important knowledge, skills and competences within the types. Source: authors 'analysis

\begin{tabular}{|l|c|c|c|}
\hline & before 1990 & $1990-2000$ & after 2000 \\
\hline CRM (N=33) & $6,1 \%$ & $39,4 \%$ & $54,5 \%$ \\
\hline MKT $(\mathrm{N}=33)$ & $21,2 \%$ & $30,3 \%$ & $48,5 \%$ \\
\hline FIN (N=39) & $2,6 \%$ & $25,6 \%$ & $71,8 \%$ \\
\hline MNG-in (N=3) & $0,0 \%$ & $33,3 \%$ & $66,7 \%$ \\
\hline MNG-ex $(\mathrm{N}=23)$ & $0,0 \%$ & $47,8 \%$ & $52,2 \%$ \\
\hline Lang $(\mathrm{N}=3)$ & $33,3 \%$ & $66,7 \%$ & $0,0 \%$ \\
\hline ICT $(\mathrm{N}=0)$ & $0,0 \%$ & $0,0 \%$ & $0,0 \%$ \\
\hline
\end{tabular}

Marketing is the most important knowledge for the oldest companies $(63,6 \%)$, while for the middle-aged it is external managerial knowledge $(23,4 \%)$ and for the youngest companies the financial knowledge $(36,8 \%)$. The focus of the knowledge type's importance of the oldest companies is almost solely on market whereas focus of both other age groups is more spread to other types (Tab. 5). This can be explained by being aware of the impact and force that market can have over the existence of companies.

Tab. 5 - Age and type of the most important knowledge, skills and competences within the age groups. Source: authors 'analysis

\begin{tabular}{|l|c|c|c|c|}
\hline & $\begin{array}{c}\text { before 1990 } \\
(\mathrm{N}=11)\end{array}$ & $\begin{array}{c}1990-2000 \\
(\mathrm{~N}=47)\end{array}$ & $\begin{array}{c}\text { after 2000 } \\
(\mathrm{N}=76)\end{array}$ & share in total \\
\hline CRM & $18,2 \%$ & $27,7 \%$ & $23,7 \%$ & $24,6 \%$ \\
\hline MKT & $63,6 \%$ & $21,3 \%$ & $21,1 \%$ & $24,6 \%$ \\
\hline FIN & $9,1 \%$ & $21,3 \%$ & $36,8 \%$ & $29,1 \%$ \\
\hline
\end{tabular}




\begin{tabular}{|l|c|c|c|c|}
\hline MNG-in & $0,0 \%$ & $2,1 \%$ & $2,6 \%$ & $2,2 \%$ \\
\hline MNG-ex & $0,0 \%$ & $23,4 \%$ & $15,8 \%$ & $17,2 \%$ \\
\hline Lang & $9,1 \%$ & $4,3 \%$ & $0,0 \%$ & $2,2 \%$ \\
\hline ICT & $0,0 \%$ & $0,0 \%$ & $0,0 \%$ & $0,0 \%$ \\
\hline total & $100,0 \%$ & $100,0 \%$ & $100,0 \%$ & $100,0 \%$ \\
\hline
\end{tabular}

The results for measurement of the degree of knowledge, skills and competencies impact on success and competitiveness in the case of age of companies are as following. For the oldest company average impact is 4,09 for the middle-aged companies it is 3,61 and for youngest companies 3,25. It seems, that the consciousness of the linkage knowledge, skills and competencies and company's success relates with the age of the companies.

\subsection{Size of companies}

Also the size of companies brings marked differences. The biggest one in the case of missing knowledge (Tab. 6) is found with internal managerial knowledge when the smallest companies do not perceived it so often as lacking (only 5,6\%) compared to the biggest companies for majority of which it seems like a problem $(72,2 \%)$. The smallest companies in hospitality are very often family-owned what can be one explanation of these findings, or the managers of such small entities believe they have everything under control.

Nearly the opposite situation is with customer relations where the managers of smallest companies introduced more often this knowledge as missing as opposed to the biggest companies $(55,6 \%$ compared to $11,1 \%)$. The question is if this missing knowledge presents a barrier for development and growth.

If we omit knowledge of languages and ICT, for more than a half of middle-sized companies marketing and financial knowledge are the most missing. Again at this point the question of barrier for growth can be raised.

Tab. 6 - Size and the most missing knowledge, skills and competencies within the types. Source: authors 'analysis

\begin{tabular}{|c|c|c|c|}
\hline & up to 10 beds & $10-50$ beds & $\begin{array}{c}\text { more than } 50 \\
\text { beds }\end{array}$ \\
\hline CRM $(\mathrm{N}=9)$ & $55,6 \%$ & $33,3 \%$ & $11,1 \%$ \\
\hline MKT (N=34) & $35,3 \%$ & $52,9 \%$ & $11,8 \%$ \\
\hline FIN (N=25) & $32,0 \%$ & $56,0 \%$ & $12,0 \%$ \\
\hline MNG-in (N=18) & $5,6 \%$ & $22,2 \%$ & $72,2 \%$ \\
\hline MNG-ex (N=34) & $38,2 \%$ & $44,1 \%$ & $17,6 \%$ \\
\hline Lang $(\mathrm{N}=7)$ & $42,9 \%$ & $57,1 \%$ & $0,0 \%$ \\
\hline ICT $(\mathrm{N}=7)$ & $28,6 \%$ & $57,1 \%$ & $14,3 \%$ \\
\hline
\end{tabular}

When analysing the results of missing knowledge within the size groups (Tab. 7), it is obvious that the biggest companies lack most often both managerial types of knowledge and as it was mentioned before, substantially more often internal managerial knowledge. With the other types 
of knowledge the frequencies are below $15 \%$. For more than $20 \%$ of middle-sized companies three types of knowledge are perceived as the most missing - marketing $(29,0 \%)$, external managerial $(24,2 \%$ and financial $(22,6 \%)$ unlike the smallest companies when just marketing $(23,7 \%)$ and external managerial knowledge $(29,5 \%)$ is the most missing knowledge for more than $20 \%$ of respondents.

Tab. 7 - Size and the most missing knowledge, skills and competencies within the size groups. Source: authors 'analysis

\begin{tabular}{|l|c|c|c|c|}
\hline & $\begin{array}{c}\text { up to } 10 \text { beds } \\
(\mathrm{N}=44)\end{array}$ & $\begin{array}{c}10-50 \text { beds } \\
(\mathrm{N}=62)\end{array}$ & $\begin{array}{c}\text { more than } 50 \\
\text { beds }(\mathrm{N}=28)\end{array}$ & $\begin{array}{c}\text { share in total } \\
(\mathrm{N}=134)\end{array}$ \\
\hline CRM & $11,4 \%$ & $4,86 \%$ & $3,6 \%$ & $6,7 \%$ \\
\hline MKT & $23,7 \%$ & $29,0 \%$ & $14,3 \%$ & $25,4 \%$ \\
\hline FIN & $18,2 \%$ & $22,6 \%$ & $10,7 \%$ & $18,7 \%$ \\
\hline MNG-in & $2,3 \%$ & $6,5 \%$ & $46,4 \%$ & $13,4 \%$ \\
\hline MNG-ex & $29,5 \%$ & $24,2 \%$ & $21,4 \%$ & $25,4 \%$ \\
\hline Lang & $6,8 \%$ & $6,5 \%$ & $0,0 \%$ & $5,2 \%$ \\
\hline ICT & $4,5 \%$ & $6,5 \%$ & $3,6 \%$ & $5,2 \%$ \\
\hline total & $100,0 \%$ & $100,0 \%$ & $100,0 \%$ & $100,0 \%$ \\
\hline
\end{tabular}

Companies do not differ very much in size categories in the case of frequencies of responses investigating the most important knowledge as it is obvious in the findings from Tab. 8. Except languages the only marked difference is with financial knowledge that are much more often appreciated as the most important by managers of middle-sized companies $(59,0 \%)$ in contrast to number of managers from biggest companies $(15,4 \%)$. The same percentage was detected with internal managerial knowledge - in every size group just the third of managers introduced this type. Another difference, but less considerable, is with external managerial knowledge where again respondents from middle-sized companies stated this knowledge more often as the most important in comparison to both other groups.

Tab. 8 - Size and type of the most important knowledge, skills and competences within the types. Source: authors 'analysis

\begin{tabular}{|l|c|c|c|}
\hline & up to 10 beds & $10-50$ beds & more than 50 beds \\
\hline CRM $(\mathrm{N}=33)$ & $42,4 \%$ & $30,3 \%$ & $27,3 \%$ \\
\hline MKT $(\mathrm{N}=33)$ & $39,4 \%$ & $42,4 \%$ & $18,2 \%$ \\
\hline FIN $(\mathrm{N}=39)$ & $25,6 \%$ & $59,0 \%$ & $15,4 \%$ \\
\hline MNG-in $(\mathrm{N}=3)$ & $33,3 \%$ & $33,3 \%$ & $33,3 \%$ \\
\hline MNG-ex $(\mathrm{N}=23)$ & $26,1 \%$ & $52,2 \%$ & $21,7 \%$ \\
\hline Lang $(\mathrm{N}=3)$ & $0,0 \%$ & $66,7 \%$ & $33,3 \%$ \\
\hline ICT $(\mathrm{N}=0)$ & $0,0 \%$ & $0,0 \%$ & $0,0 \%$ \\
\hline
\end{tabular}

There are nearly no differences among the types of knowledge and two size groups of compa- 
nies - for small and big companies three same types of knowledge are assigned as the most important - customer relations, marketing and financial. What differs is just the rank depended on slight difference in percentages. Middle-sized companies are distinct - external managerial knowledge is the type that is mentioned more often than customer relations by managers as opposed to other two groups. And difference with number of responses with financial knowledge is higher as well as it can be seen in Tab. 9 .

Tab. 9 - Size and type of the most important knowledge, skills and competences within the size groups. Source: authors 'analysis

\begin{tabular}{|l|c|c|c|c|}
\hline & $\begin{array}{c}\text { up to } 10 \text { beds } \\
(\mathrm{N}=44)\end{array}$ & $\begin{array}{c}10-50 \text { beds } \\
(\mathrm{N}=62)\end{array}$ & $\begin{array}{c}\text { more than } 50 \\
\text { beds }(\mathrm{N}=28)\end{array}$ & $\begin{array}{c}\text { share in total } \\
(\mathrm{N}=134)\end{array}$ \\
\hline CRM & $31,8 \%$ & $16,1 \%$ & $32,1 \%$ & $24,6 \%$ \\
\hline MKT & $29,5 \%$ & $22,6 \%$ & $21,4 \%$ & $24,6 \%$ \\
\hline FIN & $22,7 \%$ & $37,1 \%$ & $21,4 \%$ & $29,1 \%$ \\
\hline MNG-in & $2,3 \%$ & $1,6 \%$ & $3,6 \%$ & $2,2 \%$ \\
\hline MNG-ex & $13,6 \%$ & $19,4 \%$ & $17,9 \%$ & $17,2 \%$ \\
\hline Lang & $0,0 \%$ & $3,2 \%$ & $3,6 \%$ & $2,2 \%$ \\
\hline ICT & $0,0 \%$ & $0,0 \%$ & $0,0 \%$ & $0,0 \%$ \\
\hline total & $100,0 \%$ & $100,0 \%$ & $100,0 \%$ & $100,0 \%$ \\
\hline
\end{tabular}

Perceived degree of impact of knowledge, skills and competencies on business success and competitiveness is the highest with middle-sized companies $(3,91)$ and the lowest with big companies $(3,82)$, but as the figures together with small companies $(3,85)$ show, the differences are very small. We can conclude that size of the enterprise is not related to the perception of impact of surveyed issues on success of companies.

\subsection{Financial performance}

Tab. 10 shows findings of differences among companies according their financial performance and views of managers about the most missing types of knowledge and offers results worth of discussion. Managers of companies that are profitable in the last few years believe that the most missing type of knowledge - except languages - are the internal managerial $(66,7 \%)$ unlike companies in loss, where managers of only $5,6 \%$ of companies mentioned this type. Loss is maybe the reason why for this group of companies financial knowledge is the most often introduced as the missing one $(60,0 \%)$. What is not clear is the percentage of $12 \%$ in the case of this type of missing knowledge by the companies with profit. In survey there was no question surveying the satisfaction with financial performance and financial management, so it is not possible to formulate any probable explanation.

On the other hand, managers from companies in loss do not mention external managerial knowledge as missing at all and nearly no manager referred to the internal managerial knowledge and to marketing. Such narrow focus is maybe understandable but not the only best one in practice. 
Tab. 10 - Profit/loss and the most missing knowledge, skills and competencies within the types. Source: authors 'analysis

\begin{tabular}{|l|c|c|c|}
\hline & profit & no profit/no loss & loss \\
\hline CRM (N=9) & $33,3 \%$ & $55,6 \%$ & $11,1 \%$ \\
\hline MKT (N=34) & $26,5 \%$ & $67,6 \%$ & $5,9 \%$ \\
\hline FIN (N=25) & $12,0 \%$ & $28,0 \%$ & $60,0 \%$ \\
\hline MNG-in (N=18) & $66,7 \%$ & $27,8 \%$ & $5,6 \%$ \\
\hline MNG-ex (N=34) & $35,3 \%$ & $64,7 \%$ & $0,0 \%$ \\
\hline Lang (N=7) & $85,7 \%$ & $14,3 \%$ & $0,0 \%$ \\
\hline ICT $(\mathrm{N}=7)$ & $71,4 \%$ & $28,6 \%$ & $0,0 \%$ \\
\hline
\end{tabular}

Analysis of types of missing knowledge within profit/loss groups shows similar findings as the analysis within types of knowledge. Just the dominance of missing financial knowledge with companies in loss is even more pronounced $(78,9 \%)$. Results of profitable companies are much more diversified to various types of missing knowledge (see Tab. 11) and for companies with no profit but not in loss marketing and external managerial knowledge are introduced more often than the other types (round one third of companies). Despite their financial performance financial knowledge is mentioned as missing only by very few companies $(10,8 \%)$. This can be explain either by the good knowledge of market forces impact when financial knowledge are not so helpful or by the low level of general knowledge and competencies for management and environment.

Tab. 11 - Profit/loss and the most missing knowledge, skills and competencies within the financial performance groups. Source: authors 'analysis

\begin{tabular}{|l|c|c|c|c|}
\hline & Profit (N=50) & $\begin{array}{c}\text { no profit/no loss } \\
(\mathrm{N}=65)\end{array}$ & Loss (N=19) & $\begin{array}{c}\text { share in total } \\
(\mathrm{N}=134)\end{array}$ \\
\hline CRM & $6,0 \%$ & $7,7 \%$ & $5,3 \%$ & $6,7 \%$ \\
\hline MKT & $18,0 \%$ & $35,4 \%$ & $10,5 \%$ & $25,4 \%$ \\
\hline FIN & $6,0 \%$ & $10,8 \%$ & $78,9 \%$ & $18,7 \%$ \\
\hline MNG-in & $24,0 \%$ & $7,7 \%$ & $5,3 \%$ & $13,4 \%$ \\
\hline MNG-ex & $24,0 \%$ & $33,8 \%$ & $0,0 \%$ & $25,4 \%$ \\
\hline Lang & $12,0 \%$ & $1,5 \%$ & $0,0 \%$ & $5,2 \%$ \\
\hline ICT & $10,0 \%$ & $3,1 \%$ & $0,0 \%$ & $5,2 \%$ \\
\hline total & $100,0 \%$ & $100,0 \%$ & $100,0 \%$ & $100,0 \%$ \\
\hline
\end{tabular}

Tab. 12 shows that whereas no (or nearly no) company that is in loss does not consider customer relations, internal managerial and marketing knowledge as the most important ones $(0,0 \%$ or $3,0 \%$ ), profitable companies, or companies with relative balanced financial performance evaluate these types of knowledge just for the most important (frequencies are around 50 or more than $50 \%$ of answers). Result worth of discussion was found with internal managerial knowledge when all managers in the sample from companies that have gained no profit but they have not been in loss in the last several years indicate this type. This could also mean that internal prob- 
lems with management issues stand for the main reason of such financial performance. Unfortunately, answers do not provide any concrete explanation for such finding.

Tab. 12 - Profit/loss and type of the most important knowledge, skills and competences within the types. Source: authors 'analysis

\begin{tabular}{|l|c|c|c|}
\hline & profit & no profit/no loss & loss \\
\hline CRM $(\mathrm{N}=33)$ & $51,5 \%$ & $48,5 \%$ & $0,0 \%$ \\
\hline MKT $(\mathrm{N}=33)$ & $48,5 \%$ & $48,5 \%$ & $3,0 \%$ \\
\hline FIN $(\mathrm{N}=39)$ & $17,9 \%$ & $38,5 \%$ & $43,6 \%$ \\
\hline MNG-in $(\mathrm{N}=3)$ & $0,0 \%$ & $100,0 \%$ & $0,0 \%$ \\
\hline MNG-ex $(\mathrm{N}=23)$ & $30,4 \%$ & $65,2 \%$ & $4,3 \%$ \\
\hline Lang $(\mathrm{N}=3)$ & $100,0 \%$ & $0,0 \%$ & $0,0 \%$ \\
\hline ICT $(\mathrm{N}=0)$ & $0,0 \%$ & $0,0 \%$ & $0,0 \%$ \\
\hline
\end{tabular}

The results in the last Tab. 13 presents differences among three groups of companies divided according their financial performance and type of knowledge. For companies with profit two types of knowledge are the most often mentioned: customer relations and marketing (34\% and 32\%) while for the majority of companies in loss $(89,5 \%)$ it is financial type of knowledge. For the last group of companies the shares of various types of knowledge, namely customer relations, marketing, financial and managerial external, are almost the same - around 23 to $24 \%$. The above introduced internal managerial knowledge is not so distinct from this approach to analysis.

Tab. 13 - Profit/loss and type of the most important knowledge, skills and competences within the financial performance groups. Source: authors 'analysis

\begin{tabular}{|l|c|c|c|c|}
\hline & Profit (N=50) & $\begin{array}{c}\text { no profit/no loss } \\
(\mathrm{N}=65)\end{array}$ & Loss (N=19) & $\begin{array}{c}\text { share in total } \\
(\mathrm{N}=134)\end{array}$ \\
\hline CRM & $34,0 \%$ & $24,6 \%$ & $0,0 \%$ & $24,6 \%$ \\
\hline MKT & $32,0 \%$ & $24,6 \%$ & $5,3 \%$ & $24,6 \%$ \\
\hline FIN & $14,0 \%$ & $23,1 \%$ & $89,5 \%$ & $29,1 \%$ \\
\hline MNG-in & $0,0 \%$ & $4,6 \%$ & $0,0 \%$ & $2,2 \%$ \\
\hline MNG-ex & $14,0 \%$ & $23,1 \%$ & $5,3 \%$ & $17,2 \%$ \\
\hline Lang & $6,0 \%$ & $0,0 \%$ & $0,0 \%$ & $2,2 \%$ \\
\hline ICT & $0,0 \%$ & $0,0 \%$ & $0,0 \%$ & $5,2 \%$ \\
\hline total & $100,0 \%$ & $100,0 \%$ & $100,0 \%$ & $100,0 \%$ \\
\hline
\end{tabular}

Analysis of answer measuring the degree of impact of knowledge, skills and competencies impact on success and competitiveness revealed that financial performance probably can be factor that distinguishes companies substantially. The highest impact was found with the profitable companies $(4,63)$, while only 3,72 with the companies that are not in loss but not profitable as well and the lowest impact $(3,46)$ with the companies in a loss. This is result that could and should be surveyed more deeply because this survey does not offer any explanation. We can just hypothesize from the analysis of other answers that less successful managers perceive other bar- 
riers as more important and negatively or positively influencing their business.

\section{CONCLUSIONS}

Although only several types of knowledge, skills and competencies from all the possible in general were analysed in the presented survey, results indicate that different knowledge management strategies and practices are and should be applied when managing various types of companies in hospitality according their age, size and financial performance. Several important differences were found among companies that can have some managerial implications. For instance managers of companies that are not profitable and that are in loss introduced mostly financial knowledge as the most important knowledge and in the same time as the most missing one type while managers of profitable companies mentioned the most often customer relationship followed by marketing knowledge, skills and competencies as the most important one and both managerial knowledge (internal and external) as the most missing, nevertheless with just $24 \%$ share of companies in this group. With the first group of companies with financial performance problem (companies in loss) it would be interesting to know what are the individual reasons behind this perception (e.g. wrong decision in the past concerning some investment and/or loans; inability to calculate the prices that would ensure needed profit; knowledge and skills related to taxes etc.) and if the managers try to solve the lack of financial knowledge, skills and competencies and how do they try to solve it. The almost $90,0 \%$ share of companies in this financial performance group that introduced this type of knowledge is also worth of more detailed investigation. What can be the special issue is why they do not feel the mutual relationship among various types of knowledge, skills and competencies and the impact of various knowledge on financial performance. Although this is not exact finding from the survey, results indicate the probability of such reality.

For the oldest companies marketing knowledge is the most important while the managers of the youngest companies assigned again the financial knowledge, skills and competencies as the most important. The oldest companies miss the most internal managerial knowledge, skills and competencies and the youngest companies the marketing knowledge, skills and competencies. This findings can have their reasoning for instance in the fact that almost all oldest companies belong to the biggest ones in the sample and big companies can have problems with hierarchy, human resources management, organization, formalization as the typical examples of management barriers in big enterprises. On the contrary, the length of practice (and sustainable practice) can be associated with the very sensitive perception of market trends and their impacts on the company's existence; this is why marketing capability is appreciated so much.

The managerial knowledge, skills and competencies for managing the external environment was the most often introduced as missing by managers of the smallest companies in comparison to such knowledge but for the internal environment mentioned by the biggest companies. Managers of small (or in this sector more typically micro) companies have to deal with many distinct tasks in everyday business and monitoring and analysing the situation in the environment can be too exhaustive for them. The size of company does not enable to employ specialists in the distinct fields and relative turbulence of the environment can be evaluated as the very demanding for management.

The rank (frequencies of answers in total) of the four most important knowledge is: financial 
(1st), customer relation and marketing (2nd) and "external managerial" (3rd) and the rank for the most missing knowledge is: marketing and "external managerial" (1st), financial (2nd) and "internal managerial" (3rd).

The results for measurement of the degree of knowledge, skills and competencies impact on success and competitiveness indicate that in the case of age of companies there is direct linkage and association between these two variables - the older companies are the degree is higher. The same we can conclude with the variable of financial performance when the companies with profit perceive this impact higher compared to companies that are not in profit but not in loss as well and substantially higher in comparison to the companies in loss with There is no such relationship in the case of size of companies. These findings should be surveyed more deeply because this survey does not offer any explanation. We can just hypothesize from the analysis of other answers that less successful managers (in term of financial measures) perceive other barriers as more important and negatively or positively influencing their business and do not understand the importance of knowledge, skills and competencies or they do not understand mutual influence and relationship of different forces not only from the external but also from the internal environment and the role of human resources in the entrepreneurship and business.

Age, size and financial performance are, although not the only, indicators of quality or level of a complex general type of knowledge, skills and competences, which can be named as "general managerial". In other words, if managers' goal is the sustainable growth of company (age and size) and profitability, results for companies that were the oldest, the biggest and profitable in the survey sample, can present the benchmark for other two groups of companies. Findings can serve as the information suitable for comparison and for understanding the needs and lacks of other companies and for some changes in knowledge management.

The results offer several areas, both for next research and for reflections. Ideas for the investigation can be linked to other types of knowledge, skills and competencies, to go deeper to the internal managerial competencies (especially in the case of the higher involvement of owners into the entrepreneurship and management of companies in this industry), to the processes of searching for, staffing, training and remuneration of employees, or to commitment and motivation stimuli of both staff and managers. These last points can serve as an impetus for thinking and evaluation of concrete managerial approach to human resources. But some of the results can also serve for educational institutions and to the evaluation of their offer on the market. Some other results could be found if using more sophisticated statistics methods. This can be considered as one of the limitations of the research.

\section{References}

1. Adenfelt, M., \& Lagerström, K. (2006). Knowledge development and sharing in multinational corporations: The case of a centre of excellence and a transnational team. International Business Review, 15(4), 381-400. http://dx.doi.org/10.1016/j.ibusrev.2006.05.002

2. Aidis, R., \& Sauka, A. (2005). Entrepreneurship in the changing environment: analyzing the impact of transition stages on SME development. In: Welter, F. (ed.) Challenges in Entrepreneurship and SME Research, pp. 5-36. European Council for Small Business and Entrepreneurship, Turku Finland.

3. Bartlett, V., \& Bukvič, V. (2001). Barriers to SME growth in Slovenia. MOST: Economic Policy 
in Transitional Economies, 11(2), 177-195. http://dx.doi.org/10.1023/A:1012206414785

4. Carter, S., Mason, C., \& Tagg, S. (2004). Lifting the barriers to growth in UK small businesses. The FSB Biennial Membership Survey 2004. Glasgow: Hunter Centre for Entrepreneurship, University of Strathclyde.

5. Czech statistical office (2012). Statistical Yearbook of the Jihomoravsky Region 2010, Tourism. Retrieved from: http://www.czso.cz/csu/2011edicniplan.nsf/krajkapitola/641011-11r_2011-16

6. Conner, K. R., \& Prahalad C.K. (1996). A resource-based theory of the firm: Knowledge versus opportunism. Organization Science, 7(5), 477-501. http://dx.doi.org/10.1287/ orsc.7.5.477

7. Davenport, T.H., \& Prusak, L. (1998). What do we talk, about when we talk about knowledge? Boston: Harvard Business School Press.

8. Grant, R. M. (1996). Prospering in dynamically-competitive environments: Organizational capability as knowledge integration. Organization Science, 7(4), 375-387. http://dx.doi. org/10.1287/orsc.7.4.375

9. Greiner, M.E, Böhmann, T., \& Krcmar, H. (2007). A strategy for knowledge management. Journal of Knowledge Management, 11(6), 3-15. http://dx.doi.org/10.1108/13673270710832127

10. Gupta, A. K., \& Govindarajan,V. (2000). Knowledge flows within multinational corporations. Strategic Management Journal, 21(4), 473-496. http://dx.doi.org/10.1002/ (SICI)1097-0266(200004)21:4<473::AID-SMJ84>3.0.CO;2-I

11. Jaafar, M., Maideen, S.A., \& Sukarno, S.Z.M. (2010). Entrepreneurial characteristics of small and medium hotel owner-managers. World Applied Science Journal (Special Issue of Tourism and Hospitality), 10, 54-62.

12. Jaworski, B., \& Kohli, A.K. (1993). Market Orientation: Antecedents and Consequences. Journal of Marketing, 57(3), 53-70. http://dx.doi.org/10.2307/1251854

13. Jiménez-Jimenez, D., Valle, R.S., \& Hernandez-Esparalldo, M. (2008). Fostering innovation. The role of market orientation and organizational learning. European Journal of Innovation Management, 11(3), 389-412. http://dx.doi.org/10.1108/14601060810889026

14. Jones, E.E., \& Haven-Tang, C. (Eds.). (2005). Tourism SMEs, service quality, and destination competitiveness. Wallingford: CABI. http://dx.doi.org/10.1079/9780851990118.0000

15. Keupp, M.M., Palmié, M., \& Gassmann, O. (2011). Achieving Subsidiary Integration in International Innovation by Managerial "Tools". Management International Review, 51(2), 213 239. http://dx.doi.org/10.1007/s11575-011-0072-5

16. Kiessling, T.S., Richey, R.G., Meng, J., \& Dabic, M. (2009). Exploring knowledge management to organizational performance outcomes in a transitional economy. Journal of World Business, 44(4), 421-433. http://dx.doi.org/10.1016/j.jwb.2008.11.006

17. Klapalová, A. (2011). Barriers of entrepreneurship of SMEs in tourism and hospitality in the Region of South Moravia. In Inovácie-podnikanie-spoločnost'. Prešov: Vysoká škola medzinárodného podnikania ISM Slovakia v Prešove.

18. Nonaka, I., \& Takeuchi, H. (1995). The Knowledge Creating Company. Oxford: Oxford University Press.

19. Pasanen, M. (2005). Tracking small business failure factors and trajectories. In F. Welter (Ed.), 
Challenges in Entrepreneurship and SME Research (93-113). European Council for Small Business and Entrepreneurship, Turku: Finland.

20. Quintas, P., Lefrere, P., \& Jones, G. (1997). Knowledge management: a strategic agenda. Long Range Planning, 30(3), 385-391. http://dx.doi.org/10.1016/S0024-6301(97)90252-1

21. Sudsakorn, T., \& Swierczek, F. W. (2009). Management competencies: a comparative study between Thailand and Hong Kong. Journal of Management Development, 28(7), 569-580. http:// dx.doi.org/10.1108/02621710910972689

22. Yilmaz, B.S. (2009). Competitive advantage strategies for SMEs in tourism sector: a case study. MIBES Transactions, 3(1), 157-171.

23. Wang, C., Walker, E.A., \& Redmond, J. (2007). Explaining the lack of strategic planning in SMEs: The importance of owner motivation. International Journal of Organisational Behaviour, 12(1), 1-16.

24. Zack, M.H. (1999). Developing a knowledge strategy. California Management Review, 41 (3), 125-145. http://dx.doi.org/10.2307/41166000

\section{Contact information}

Alena Klapalová, Ph.D.

College of Hotel Management and Commerce

Bosonožská 9, 62500 Brno, Czech Republic

Email:klapalova@hotskolabrno.cz.

JEL Classification: D21, D83, J2, L8 